\title{
Ki-67 as prognostic marker in early breast cancer: a meta-analysis of published studies involving 12 I 55 patients
}

\author{
E de Azambuja', , F Cardoso', G de Castro Jr', M Colozza ${ }^{3}$, MS Mano', V Durbecq', C Sotiriou', D Larsimont', \\ MJ Piccart-Gebhart' and M Paesmans*,4 \\ 'Medical Oncology Clinic, Jules Bordet Institute, 125 Boulevard de Waterloo, 1000, Brussels, Belgium; ${ }^{2}$ PhD student in the Programa de Pós-graduação \\ em Medicina, Ciências Médicas, Faculdade de Medicina, Universidade Federal do Rio Grande do Sul, 2400 Ramiro Barcelos, 90035-003, Porto Alegre, \\ Brazil; ${ }^{3}$ SC Oncologia Medica, Azienda Ospedaliera, Via Brunamonti, 5 I-06122, Perugia, Italy; ${ }^{4}$ Data Centre, Jules Bordet Institute, 125 Boulevard de \\ Waterloo, 1000, Brussels, Belgium
}

The Ki-67 antigen is used to evaluate the proliferative activity of breast cancer (BC); however, Ki-67's role as a prognostic marker in $B C$ is still undefined. In order to better define the prognostic value of Ki-67/MIB-I, we performed a meta-analysis of studies that evaluated the impact of Ki-67/MIB-I on disease-free survival (DFS) and/or on overall survival (OS) in early BC. Sixty-eight studies were identified and 46 studies including 12155 patients were evaluable for our meta-analysis; 38 studies were evaluable for the aggregation of results for DFS, and 35 studies for OS. Patients were considered to present positive tumours for the expression of Ki67/MIB-I according to the cut-off points defined by the authors. Ki-67/MIB-I positivity is associated with higher probability of relapse in all patients $(\mathrm{HR}=1.93$ (95\% confidence interval $(\mathrm{Cl})$ : I.74-2.I4); $P<0.00 \mathrm{I})$, in node-negative patients $(\mathrm{HR}=2.3 \mathrm{I}(95 \% \mathrm{Cl}: \mathrm{I} .83-$ 2.92); $P<0.00 \mathrm{I})$ and in node-positive patients $(\mathrm{HR}=1.59(95 \% \mathrm{Cl}: 1.35-1.87) ; P<0.00 \mathrm{I})$. Furthermore, Ki-67/MIB-I positivity is associated with worse survival in all patients $(H R=1.95(95 \% \mathrm{Cl}: 1.70-2.24 ; P<0.00 \mathrm{I}))$, node-negative patients $(\mathrm{HR}=2.54(95 \% \mathrm{Cl}$ : I.65-3.9I); $P<0.00 \mathrm{I})$ and node-positive patients $(H R=2.33(95 \% \mathrm{Cl}: \mathrm{I} .83-2.95) ; \mathrm{P}<0.00 \mathrm{I})$. Our meta-analysis suggests that Ki-67/ MIB-I positivity confers a higher risk of relapse and a worse survival in patients with early BC. British Journal of Cancer (2007) 96, I504- 1513. doi:I0.1038/sj.bjc.6603756 www.bjcancer.com

Published online 24 April 2007

(c) 2007 Cancer Research UK

Keywords: breast cancer; Ki-67; prognostic value; meta-analysis

The crude incidence of breast cancer (BC) in Europe is 109.8/ 100.000 women per year and it is responsible for 38.4 out of 100.000 deaths per women annually (Pestalozzi et al, 2005). Significant improvements in both disease-free survival (DFS) and overall survival (OS) have been obtained with the extensive use of adjuvant systemic therapies (EBCTCG, 2005). In the last few decades, proliferation markers have been extensively evaluated as prognostic tools in $\mathrm{BC}$. However, the only prognostic factors utilised in clinical decision making are some histologic features (e.g. tumour size, histologic grade, nodal status and lymphovascular invasion), hormone receptor status, HER-2 status and age (Colozza et al, 2005; Hayes, 2005).

$\mathrm{Ki}-67$ is present in all proliferating cells and there is great interest in its role as a marker of proliferation (Gerdes et al, 1983). The Ki-67 antibody reacts with a nuclear non-histone protein of $395 \mathrm{KD}$ present in all active phases of the cell cycle except the G0 phase (Cattoretti et al, 1992). MIB-1 is a monoclonal antibody against recombinant parts of the Ki-67 antigen; a good correlation exists between Ki-67 and MIB-1 (Cattoretti et al, 1992).

Recently, gene array techniques have revealed the Ki-67 gene's role in several 'proliferation signatures', showing that a set of genes with increased expression patterns is correlated with tumour cell

\footnotetext{
*Correspondence: M Paesmans; E-mail: marianne.paesmans@bordet.be This article was partially presented at the San Antonio Breast Cancer Symposium 2005.

Received I8 January 2007; revised 26 March 2007; accepted 26 March 2007; published online 24 April 2007
}

proliferation rates, as assessed by the Ki-67 labelling index (Perou et al, 1999; Whitfield et al, 2006). Moreover, Ki-67 is one of the 21 prospectively selected genes of the Oncotype $\mathrm{DX}^{\mathrm{TM}}$ assay used to predict the risk of recurrence in a node-negative, tamoxifentreated BC population enrolled in the National Surgical Adjuvant Breast and Bowel Project B-14 (NSABP B-14), as well to predict the magnitude of chemotherapy benefit in women with node-negative, estrogen receptor (ER)-positive BC enrolled in the NSABP B20 trial (Paik et al, 2004, 2006).

Despite the large number of published papers analyzing the prognostic role of $\mathrm{Ki}-67$ in early $\mathrm{BC}$, it is still not considered as an established factor to be used in clinical practice, probably because most of the studies are retrospective and because some uncertainty remains on the way Ki-67 should be assessed (Eifel et al, 2001; Goldhirsch et al, 2003; Colozza et al, 2005; Urruticoechea et al, 2005). Therefore, due to the fact that a more convincing demonstration of the Ki-67 prognostic role, in early BC, would be of value for initiating further research on the assessment methods of Ki-67, we performed this literature-based metaanalysis to better quantify the prognostic impact of Ki-67 expression.

\section{MATERIALS AND METHODS}

\section{Publication selection}

For this meta-analysis, we selected studies evaluating the relationship between Ki-67/MIB-1 status and prognosis in early BC 
published until May 2006. To fulfill our selection criteria, the studies had to have been published as a full paper in English. Articles were identified by an electronic PubMed search using the following keywords: 'breast cancer','Ki-67','MIB-1','proliferative index', 'proliferative marker', 'survival' and 'prognostic'. We also screened references from the relevant literature, including all the identified studies and reviews. To avoid duplicate data, we identified articles that included the same cohort of patients by reviewing interstudy similarity in the country in which the study was performed, investigators in the study, source of patients, recruitment period and inclusion criteria. Therefore, when the authors reported the same patient population in several publications, only the most recent or complete study was included in this analysis.

\section{Data extraction}

Information was carefully extracted from all publications by three authors (EA, GC and MP). The following data were collected from each study: publication date, first author's last name, antibody and cut-off used for assessing Ki-67 positivity, distribution of Ki-67 status, follow-up period, treatment, nodal status and data allowing us to estimate the impact of Ki-67 expression on DFS and/or OS.

We did not define any minimal number of patients to include a study in our meta-analysis, nor a minimal duration of median follow-up. The exclusion criteria are described below and were not driven by the study individual results.

\section{Statistical methods}

Ki-67 was considered positive or negative according to the cut-off values provided by the authors. For the quantitative aggregation of the survival results, the impact of Ki-67 expression on prognosis was measured using Hazard Ratio (HR). For each study, this HR was estimated by a method depending on the results provided in the original publication. The most accurate method was to retrieve the estimated HR and its variance using two of the following parameters: the HR point estimate, the log-rank statistic or its $P$-value, and the $\mathrm{O}-\mathrm{E}$ statistic (difference between numbers of observed and expected events) or its variance. If those data were not available, we looked for the total number of events, the number of patients at risk in each group and the log-rank statistic or its $P$-value, to estimate the HR. Finally, if the only useful data were in the form of graphical representations of the survival distributions, we extracted from them the survival rates at specified time-points in order to reconstruct the HR estimate and its variance, with the assumption that the rate of patients censored was constant during the study follow-up (Parmar et al, 1998).

Three independent persons read the curves to reduce reading variability. If authors reported survival of three or more groups, we pooled the results to make feasible a comparison between two groups. Whenever possible, HR estimates for subgroups were calculated, such as in node-negative, node-positive or untreated patients. Results were crosschecked with those from the original publication to be sure that they are not discrepant, in particular when reading of the survival rates had to be performed on the survival curves.

The individual HR estimates were combined into an overall HR using the Peto's method that was first used and published in 1985 (Yusuf et al, 1985). We carried out heterogeneity $\chi^{2}$-tests, and if the assumption of homogeneity of individual HRs had to be rejected, we used a random-effect model in place of a fixed-effect model. By convention, an observed HR $>1$ implied a worse prognosis for the group with positive $\mathrm{Ki}-67$ expression. This impact of $\mathrm{Ki}-67$ on survival was considered to be statistically significant if the $95 \%$ confidence interval (CI) for the overall HR did not overlap 1 . We have used the authors' definitions for DFS and OS.
All the statistical calculations for our meta-analysis were performed with personal computing.

\section{RESULTS}

\section{Characteristics of the studies}

Out of 68 studies published between the years 1989 and 2006, 46 had the sufficient information for HR extraction, including 38 studies evaluable for DFS and 35 for OS, some of them being evaluable for only one of these end points, or they analysed only one of these end points. Tables 1 and 2 list the evaluable studies with their main characteristics, and Table 3 presents the main results of this meta-analysis. The reasons to consider an article as non-evaluable were: (a) no univariate analysis reported; (b) no possibility to calculate HR using one of the methods mentioned above due to the fact that the distribution of $\mathrm{Ki}-67$ was not reported in the article, or sometimes Ki-67 was analysed in combination with other prognostic markers rendering the analysis impossible; (c) overlapping data published in different journals; and (d) inclusion of metastatic BC patients. Table 4 lists all the studies considered non-evaluable for this meta-analysis, but used at sensitivity analysis.

The number of patients included across all studies varied from 42 to 863 , and the follow-up period varied from 23.6 months (mean) to 16.3 years (median). Different antibodies were used through all trials: anti-Ki-67 was used in 24 studies (52.1\%), antiMIB-1 in 24 studies (52.1\%), both antibodies were performed in five studies (Keshgegian and Cnaan, 1995; Veronese et al, 1995; Bevilacqua et al, 1996; Querzoli et al, 1996; Billgren et al, 2002), anti-Ki-S5 in two studies (Rudolph et al, 1999a; Esteva et al, 2004) and anti-Ki-S11 in one study (Rudolph et al, 1999b). The different cut-off values used were those of the authors (range: 3.5-34\%). Threshold definitions were mean or median values, the best cut-off value or an established arbitrary value.

Out of the 38 evaluable studies for DFS (10954 patients), subgroup analysis was possible in 15 studies with node-negative patients (3370 patients) (Sahin et al, 1991; Weikel et al, 1991, 1995; Gaglia et al, 1993; Bevilacqua et al, 1996; Brown et al, 1996; Pierga et al, 1996; Railo et al, 1997; Jansen et al, 1998; Clahsen et al, 1999; Harbeck et al, 1999; Rudolph et al, 1999a; Billgren et al, 2002; Trihia et al, 2003; Erdem et al, 2005), in eight with node-positive patients (1430 patients) (Weikel et al, 1991, 1995; Gaglia et al, 1993; Pierga et al, 1996; Jansen et al, 1998; Billgren et al, 2002; Trihia et al, 2003; Esteva et al, 2004) and in six with untreated nodenegative patients (736 patients) (Sahin et al, 1991; Weikel et al, 1991; Bevilacqua et al, 1996; Railo et al, 1997; Jansen et al, 1998; Harbeck et al, 1999). Regarding OS (9472 patients), of all 35 studies, subgroup analysis was possible in nine studies with nodenegative patients (1996 patients) (Jensen et al, 1995; Weikel et al, 1995; Bevilacqua et al, 1996; Brown et al, 1996; Domagala et al, 1996; Fresno et al, 1997; Rudolph et al, 1999a; Trihia et al, 2003; Erdem et al, 2005), in four with node-positive patients (857 patients) (Weikel et al, 1995; Domagala et al, 1996; Gonzalez et al, 2003; Trihia et al, 2003) and in two that included only untreated patients (node-negative and node-positive) (284 patients) (Pinder et al, 1995; Bevilacqua et al, 1996).

\section{Meta-analysis}

The main meta-analyses results (overall population and DFS/OS) are shown in Figures 1 and 2. For the overall population, worse DFS (HR 1.93, 95\% CI 1.74-2.14; $P<0.001$ ) and OS (HR $1.95,95 \%$ CI $1.70-2.24 ; P<0.001)$ were observed among patients considered as $\mathrm{Ki}-67$ positive. Worse prognosis was observed independently both in node-negative (DFS (HR 2.31, 95\% CI 1.83-2.92; $P<0.001$ ); OS (HR 2.54, 95\% CI 1.65-3.91; $P<0.001)$ ) and in 
Table I Main characteristics of all studies included in the meta-analysis for overall survival

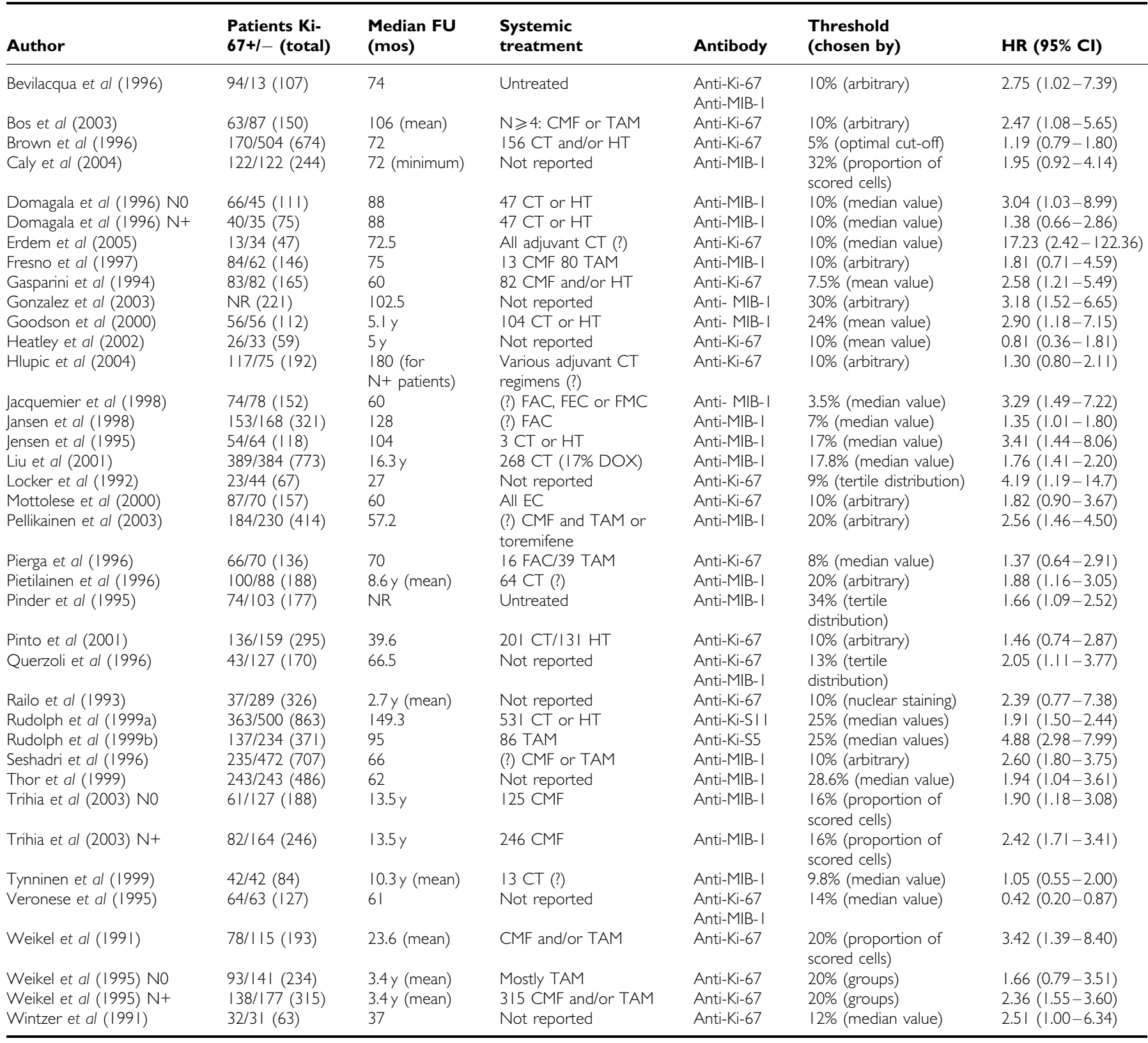

$\mathrm{Cl}$, confidence interval; CMF, cyclophosphamide, methotrexate, 5-fluorouracil; CT, chemotherapy; DOX, doxorubicin; EC, epirubicin, cyclophosphamide; FAC, 5-fluorouracil, doxorubicin, cyclophosphamide; FEC, 5-fluorouracil, epirubicin, cyclophosphamide; FMC, 5-fluorouracil, mitoxantrone, cyclophosphamide; FU, follow-up; HR, hazard ratio; HT, hormonotherapy; mos, months; No, node-negative; N+, node-positive; NR, not reported; TAM, tamoxifen; +, positive; -, negative; y, years.

node-positive patients (DFS (HR 1.59, 95\% CI 1.35-1.87; $P<0.001$ ); OS (HR 2.33, 95\% CI $1.83-2.95 ; P<0.001)$ ). For the untreated patients subgroup analysis, worse DFS was found in all node-negative patients (HR 2.72, 95\% CI 1.97-3.75; $P<0.001$ ), as well as worse OS in node-negative and node-positive patients taken together (HR1.79, 95\% CI 1.22-2.63; $P=0.001$ ).

The necessity to exclude some studies due to a lack of results for aggregating the results is a well-known important problem when conducting a meta-analysis, because the excluded studies show often a smaller effect compared to the studies published with full details and evaluable for the meta-analysis. To assess the impact of bias related to the unevaluable studies (that might lead to an overestimation of the effect), we performed an analysis on the overall patient populations including both evaluable and unevaluable studies. For papers reporting only HR estimates obtained in multivariate analyses, we used this HR estimate together with its variance. For those with uncertainties related to the number of events and then the variance of the HR estimate, we made rough approximation of the variance. Finally, for the studies where no useful information could be retrieved from the publication, we considered that the HR estimate was 1 (i.e. no impact at all for $\mathrm{Ki}-67$ ) and used a minimal variance compared to the included studies of the same size. Even by carrying out this sensitivity analysis, we still observe a significant pejorative impact of Ki-67 positivity on DFS (HR $1.74,95 \%$ CI 1.56-1.95; $P<0.001$; heterogeneity test $P<0.001)$ and OS (HR 1.76, 95\% CI 1.54-2.00; $P<0.001$; heterogeneity test $P<0.001)$. 
Table 2 Main characteristics of all studies included in the meta-analysis for disease-free survival

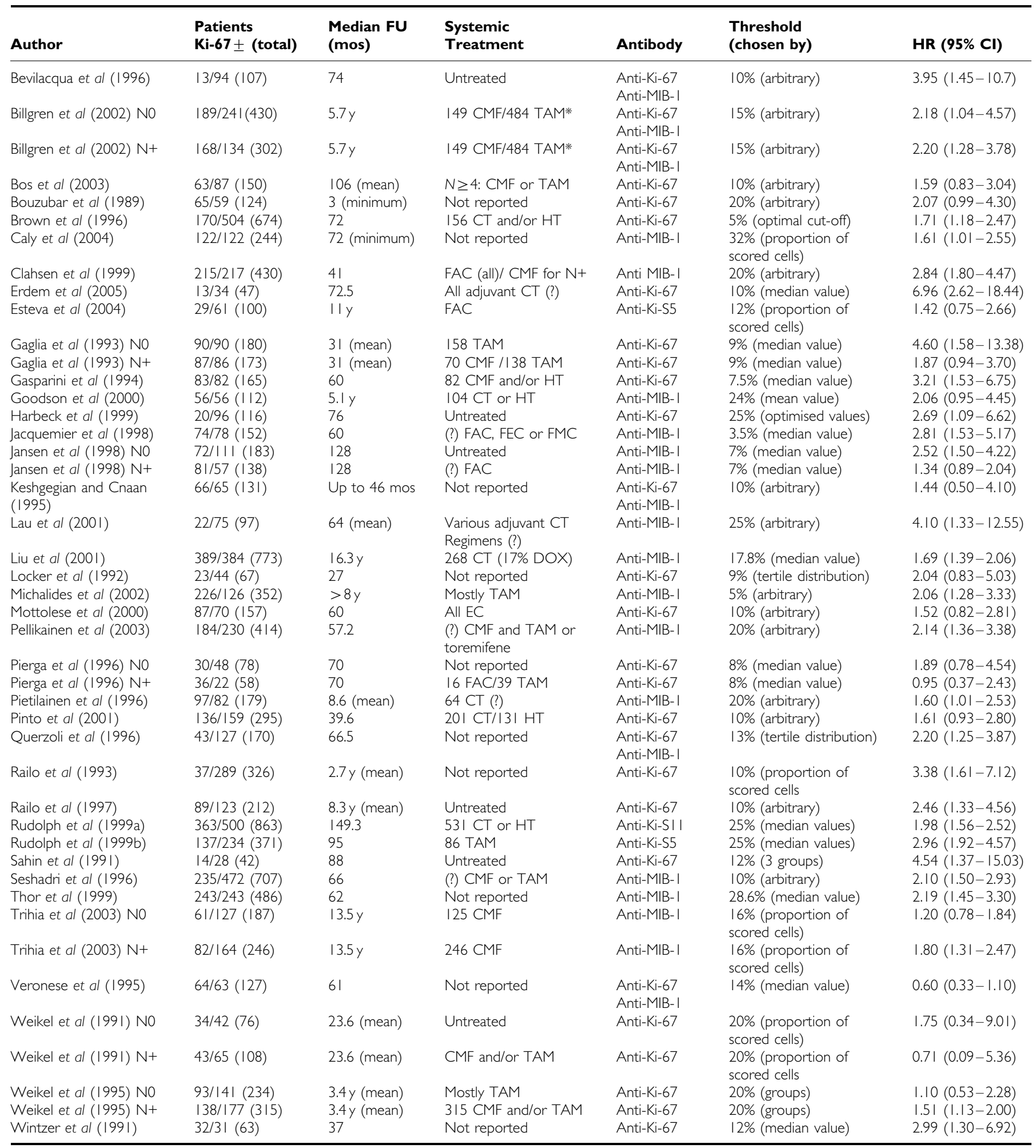

$\mathrm{Cl}$, confidence interval; CMF, cyclophosphamide, methotrexate, 5-fluorouracil; CT, chemotherapy; DOX, doxorubicin; EC, epirubicin, cyclophosphamide; FAC, 5-fluorouracil, doxorubicin, cyclophosphamide; FEC, 5-fluorouracil, epirubicin, cyclophosphamide; FMC, 5-fluorouracil, mitoxantrone, cyclophosphamide; FU, follow-up; HR, hazard ratio; mos, months; NO, node-negative; N+, node-positive; NR, not reported; TAM, tamoxifen; $y$, years; +, positive; - , negative. *For total population $(n=732)$

\section{DISCUSSION}

The present meta-analysis confirms that high Ki-67 expression in patients with early BC confers worse prognosis in the overall population and quantifies its prognostic univariate impact. Further, it was also shown in subgroup analyses for node-negative, node-positive and untreated patients. This is the first metaanalysis of published studies to evaluate the association between 
Table 3 HR values and heterogeneity test for all subgroups analysis in patients with early breast cancer

\begin{tabular}{|c|c|c|c|c|c|}
\hline Group & Number of studies & Number of patients & $\begin{array}{l}\text { Fixed effect HR } \\
(95 \% \mathrm{CI})\end{array}$ & $\begin{array}{l}\text { Heterogeneity test } \\
\text { (P-value) }\end{array}$ & $\begin{array}{c}\text { Random effect HR } \\
(95 \% \mathrm{Cl})\end{array}$ \\
\hline \multicolumn{6}{|l|}{ Disease-free survival } \\
\hline All pts & 38 & 10954 & $1.88(1.75-2.02)$ & 0.01 & $1.93(1.74-2.14)$ \\
\hline$N-$ pts & 15 & 3370 & $2.20(1.88-2.58)$ & 0.03 & $2.31(1.83-2.92)$ \\
\hline $\mathrm{N}+$ pts & 8 & 1430 & $1.59(1.35-1.87)$ & 0.68 & \\
\hline $\mathrm{N}-$ untreated pts & 6 & 736 & $2.72(1.97-3.75)$ & 0.89 & \\
\hline \multicolumn{6}{|l|}{ Overall survival } \\
\hline All pts & 35 & 9472 & $1.89(1.74-2.06)$ & $<0.001$ & $1.95(1.70-2.24)$ \\
\hline $\mathrm{N}-\mathrm{pts}$ & 9 & 1996 & $2.19(1.76-2.72)$ & 0.001 & $2.54(1.65-3.91)$ \\
\hline $\mathrm{N}+$ pts & 4 & 857 & $2.33(1.83-2.95)$ & 0.44 & \\
\hline $\mathrm{N}-/ \mathrm{N}+$ untreated pts & 2 & 284 & $1.79(1.22-2.63)$ & 0.36 & \\
\hline
\end{tabular}

Cl: confidence interval; HR: hazard ratio; $\mathrm{N}$-: node-negative; $\mathrm{N}+$ : node-positive; pts: patients.

Table 4 Studies that were not evaluable for this meta-analysis, but included in the sensitivity test

\begin{tabular}{lcl}
\hline Author & $\begin{array}{c}\text { Number of } \\
\text { patients }\end{array}$ & $\begin{array}{l}\text { Ki-67 prognostic } \\
\text { value (Yes/No) }\end{array}$ \\
\hline Beck et al (1995) & 462 & Yes \\
Biesterfeld et al (1998) & 103 & Yes \\
Bukholm et al (2003) & 147 & No \\
Ceccarelli et al (2000) & 217 & Yes \\
Galiegue et al (2004) & 117 & No \\
Gasparini et al (1992) & 164 & Yes \\
Haerslev et al (1996) & 487 & Yes \\
Jalava et al (2000) & 414 & No \\
Kroger et al (2006) & 157 & Yes \\
Kronblad et al (2006) & 377 & Yes \\
Lampe et al (1998) & 142 & Yes \\
Liu et al (2000) & 225 & No \\
Michels et al (2003) & 104 & Yes \\
Molino et al (1997) & 322 & No \\
Rudas et al (1994) & 184 & Nos \\
Tsutsui et al (2005) & 249 & \\
Yang et al (2003) & 147 & \\
\hline
\end{tabular}

Ki-67/MIB-1 expression and prognosis in early BC. Prognostic markers may be defined as those markers that are associated with some clinical outcomes, typically a time-to-event outcome such as OS or DFS, independently of any treatment or intervention. The best setting to apply this concept is in untreated populations, which helps identifying the so-called pure prognostic marker. Prognostic markers may also be used to aid the decision-making process for adjuvant therapy, for example, they may be used as decision aids in determining whether a patient should receive adjuvant chemotherapy or how aggressive that therapy should be (McShane et al, 2005).

$\mathrm{Ki}-67$ has been assayed in many studies as a prognostic and/or predictive marker in early BC. As a predictive marker, very few trials of primary systemic therapy, mostly retrospective and with conflicting results have been published (Colozza et al, 2005), and therefore we felt that the assessment of the predictive role of Ki-67 was out of scope for this meta-analysis.

Our meta-analysis was carried out using literature published results, and we therefore acknowledge some limitations of our approach which is, however, much less expensive than a metaanalysis using individual patients data. The language selection could favour positive studies, following the assumption that they are more often published in English, whereas the negative ones tend to be published more often in local journals using the author's native languages (Egger et al, 1997). However, we did not identify many papers published in a national language (Italian, Russian, Serbian, German) (Lelle, 1990; Topic et al, 2002; Kushlinskii et al, 2004; Costarelli et al, 2005). This may be called the 'Tower of Babel bias' and, in at least one of 36 consecutive meta-analyses, the exclusion of papers for linguistic reasons produced different results from those which would have been obtained if this exclusion criterion had not been used (Gregoire et al, 1995). Another possible source of confusion is the use of the same cohort of patients in different publications, although studies that were clearly based on the analysis of the same patient cohorts were excluded in this meta-analysis.

Some authors consider meta-analyses using individual data to be the gold standard evidence (Stewart and Parmar, 1993; Oxman et al, 1995). This approach is normally considered to be a new study that takes into account all performed studies on the topic, published or not, and that requires an individual data update by the investigators; it is thus much more time consuming, complex and costly. In a comparison between a meta-analysis based on individual patient data and one based on extracted data, the overall duration for the former was found to be 1-5 years while for the latter it is only 1-5 months. Additionally, the overall cost to perform an individual patient data meta-analysis is $\$ 50000$ to $\$ 500000$, whereas for an extracted data study it is in the range of $\$ 5000$ to $\$ 30000$ (Piedbois and Buyse, 2004). Therefore, a metaanalysis on published literature is worthwhile and, especially in a situation, as here, it is very unlikely to find the resources to conduct a meta-analysis based on the individual data.

The method used for extrapolating HR might be a source of some variability in the HR estimates. When no other useful information was available, we extrapolated the HR from the survival curves using several time points during follow-up for reading the corresponding survival rates, assuming that censored observations were uniformly distributed. The estimation of survival rates based on the graphical representation of the survival curves was performed independently by three of the authors and we compared our HR estimate and its statistical significance with the results published in each individual trial. We did not identify any major contradiction between our results and the results available in the papers.

The adverse impact of Ki-67 positivity on both OS and DFS was observed in the overall population as well as in the subgroups node-negative and node-positive patients. Significant heterogeneity was detected when considering the whole population and node-negative patients. It is not considered appropriate to define a single measure (i.e. HR associated with $\mathrm{Ki}-67$ positivity in this case) from studies with inherent dissimilarities. The observed disparity among the conclusions of different studies, responsible for the observed heterogeneity, can be quantified by applying 


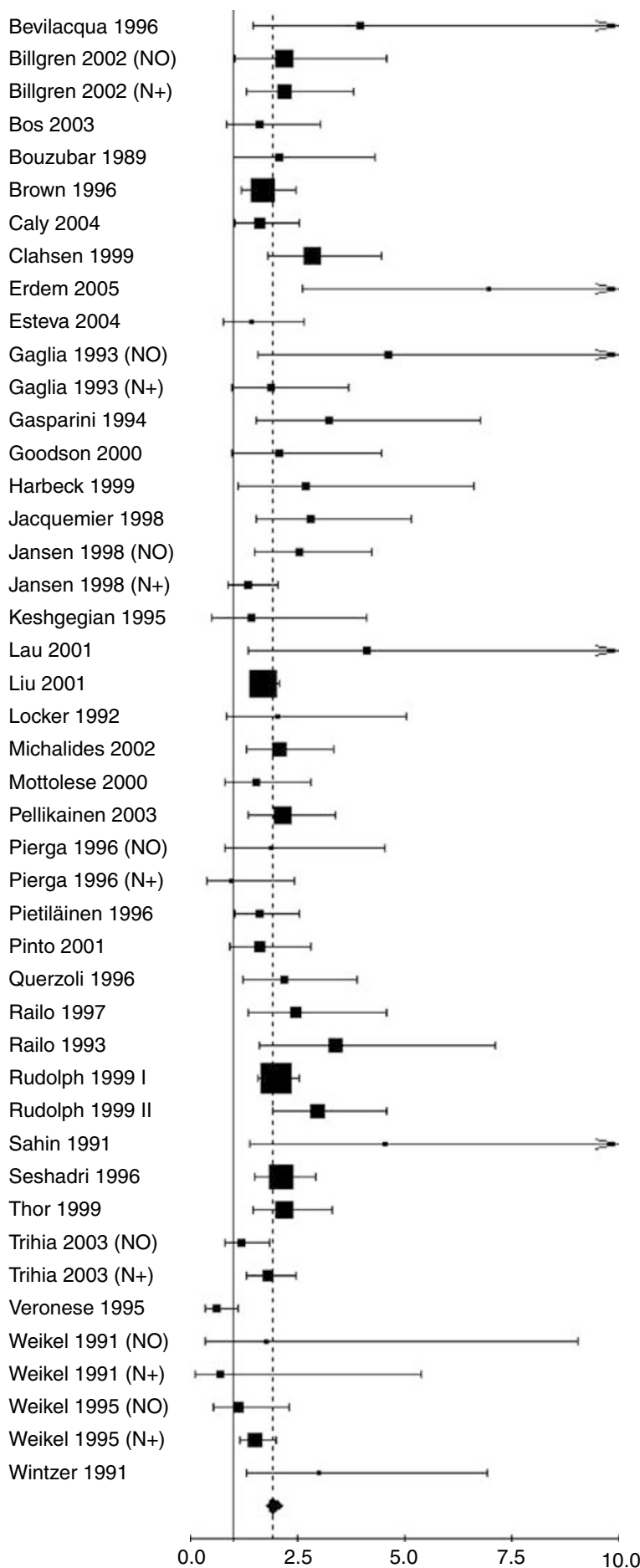

Figure I Results of the meta-analysis with all evaluable studies for DFS. A hazard ratio $(H R)>I$ implies a worse DFS for the group with increased $\mathrm{Ki}-67$. The squared size is proportional to the number of patients included in each study. The centre of the lozenge gives the combined HR for the meta-analysis and its extremities the $95 \% \mathrm{Cl}$.

quality scores to the selected studies included in the meta-analysis. However, these scores do not always explain the observed results (Greenland, 1994). In this case, the methodological characteristics of each study must be taken into consideration.

In 1992, Cattoretti et al (1992) reported better success in staining Ki-67 in paraffin-embedded samples after the new

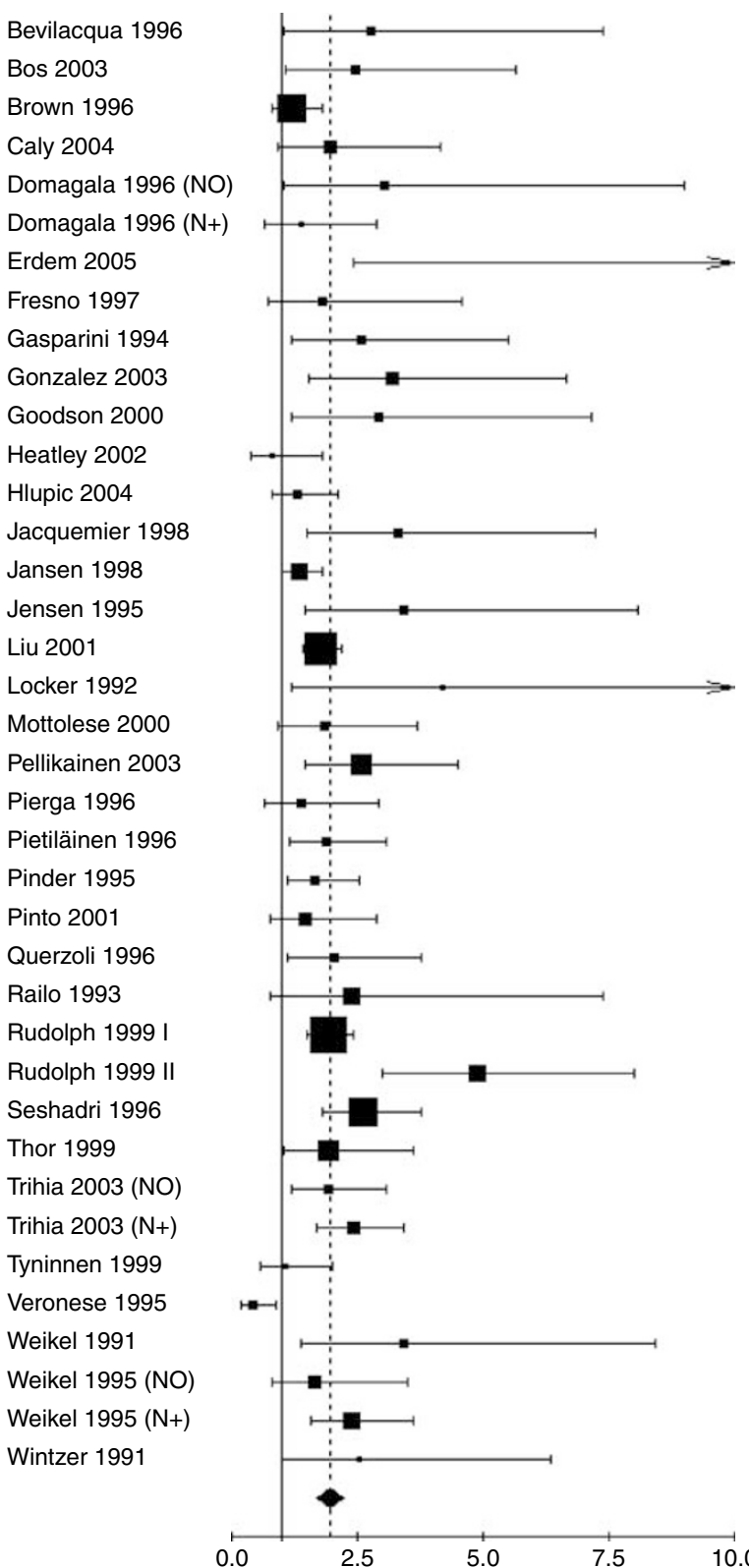

Figure 2 Results of the meta-analysis with all evaluable studies for OS. A $H R>I$ implies a worse OS for the group with increased Ki-67. The squared size is proportional to the number of patients included in each study. The centre of the lozenge gives the combined HR for the metaanalysis and its extremities the $95 \% \mathrm{Cl}$.

antibodies anti-MIB-1 and anti-MIB-3 had been developed. Although several antibodies are now commercially available to stain Ki-67, anti-MIB-1 is the most frequently used in recent studies (Urruticoechea et al, 2005). In our meta-analysis, antibodies other than anti-MIB-1 and anti-Ki-67 were included, such as anti-KiS5 (Rudolph et al, 1999a; Esteva et al, 2004) and anti-Ki-S11 (Rudolph 
Table 5 Main results from the recent gene expression signatures in breast cancer

\begin{tabular}{|c|c|c|c|}
\hline Gene expression signature & $\begin{array}{l}\text { Number of genes in } \\
\text { the signature }\end{array}$ & Description of genes in the signature & Reference \\
\hline 70-gene signature & 70 & Cell cycle, angiogenesis, invasion and metastasis & van't Veer et al (2002) \\
\hline 76-gene signature & 76 & Cell cycle, proliferation, DNA repair, immune response and apoptosis & Wang et al (2005) \\
\hline Genomic grade index & 97 & Cell cycle and proliferation genes & Sotiriou et al (2006) \\
\hline p53-signature & 32 & Proliferation genes and transcription factors (not p53 targets) & Miller et al (2005) \\
\hline
\end{tabular}

et al, 1999b), albeit representing only a minority of the cases. Moreover, Ki-67 expression is usually estimated as the percentage of tumour cells positively stained by the antibody, with nuclear staining being the most common criteria of positivity. The use of different antibodies and scoring protocols without a standard minimum number of cells to be counted may account for some of the differences between the studies.

In our meta-analysis, some studies have used $10 \%$ as the cut-off (arbitrary value), whereas others have chosen mean, median, the optimal cut-off value or arbitrary values, and these differences might be responsible for the difficulty in determining a standard threshold in daily practice. However, some authors have described that the choice of the cut-off point for IHC may depend on the clinical objective: if $\mathrm{Ki}-67$ is used to exclude patients with slowly proliferating tumours from chemotherapeutic protocols, a cut-off of $10 \%$ will help avoid overtreatment. In contrast, if Ki-67 is used to identify patients sensitive to chemotherapy protocols, it is preferable to set the cut-off at 25\% (Spyratos et al, 2002). In the context of this meta-analysis, we may assume that increased Ki-67 leads to an increased risk of relapse and/or death and that a relative increase is estimated although the baseline risk (the risk in the group considered Ki-67 negative) is not the same in all the studies.

A further limitation of our meta-analysis is that it assesses only the univariate prognostic value of Ki-67. So, we cannot infer from our meta-analysis that $\mathrm{Ki}-67$ is an independent factor; the answer to that question should come from a prospective study (it is likely that a meta-analysis of individual data would not solve the question as the intersection of the sets of covariates available in the individual studies is most probably very small).

To better clarify the prognostic role of ER status, Sotiriou et al (2006) used gene array profiling to explore the implications of the joint distribution of ER status and gene expression grade index (GGI) to predict clinical outcome. They found that almost all ER-negative tumours were associated with high GGI scores (high grade), whereas ER-positive tumours were associated with a heterogeneous mixture of GGI values. This means that GGI adds additional prognostic information when the ER status is known, whereas the opposite is not true. Unfortunately, due to the lack of information in the published studies used in our study, an analysis of the impact of Ki-67 expression on the ER-negative and ER-positive subpopulations and grade, which are well-known risk factor associated with worse outcome, was not possible. Table 5 summarises the main results of the recent genes signatures for prognosis/prediction in $\mathrm{BC}$.

Despite years of research and hundreds of reports of tumour markers in oncology, the number of markers that have emerged as clinically useful is quite small. The REporting of tumour MARKer Studies (REMARK) guidelines was the major task of the NCIEORTC First International Meeting on Cancer Diagnosis, representing a collaborative effort of statisticians, clinicians and laboratory scientists. The guidelines contain 20 recommendations derived from studies on tumour markers and regarding study design, methods of statistical analysis, preplanned hypotheses, patient and specimen characteristics, and assay methods. The widespread use of published guidelines for analytical methods and the reporting of results would greatly facilitate the development of alternative analyses and meta-analyses (Alonzo, 2005; McShane et al, 2005).

Despite some limitations, this meta-analysis supports the prognostic role of $\mathrm{Ki}-67$ in early $\mathrm{BC}$, by showing a significant association between its expression and the risk of recurrence and death in all populations considered and for both outcomes, DFS and OS. Had the proposed REMARK guidelines been employed in all the studies selected for this meta-analysis and had all necessary information been available, our literature-based meta-analysis would better characterise the role of Ki-67 as prognostic marker.

\section{ACKNOWLEDGEMENTS}

We thank Carolyn Straehle for her editorial assistance.

\section{REFERENCES}

Alonzo TA (2005) Standards for reporting prognostic tumor marker studies. J Clin Oncol 23: $9053-9054$

Beck T, Weller EE, Weikel W, Brumm C, Wilkens C, Knapstein PG (1995) Usefulness of immunohistochemical staining for p53 in the prognosis of breast carcinomas: correlations with established prognosis parameters and with the proliferation marker, MIB-1. Gynecol Oncol 57: 96-104

Bevilacqua P, Verderio P, Barbareschi M, Bonoldi E, Boracchi P, Dalla Palma P, Gasparini G (1996) Lack of prognostic significance of the monoclonal antibody Ki-S1, a novel marker of proliferative activity, in node-negative breast carcinoma. Breast Cancer Res Treat 37: 123-133

Biesterfeld S, Kluppel D, Koch R, Schneider S, Steinhagen G, Mihalcea AM, Schroder W (1998) Rapid and prognostically valid quantification of immunohistochemical reactions by immunohistometry of the most positive tumour focus. A prospective follow-up study on breast cancer using antibodies against MIB-1, PCNA, ER, and PR. J Pathol 185: 25-31

Billgren AM, Tani E, Liedberg A, Skoog L, Rutqvist LE (2002) Prognostic significance of tumor cell proliferation analyzed in fine needle aspirates from primary breast cancer. Breast Cancer Res Treat 71: 161-170

Bos R, van der Groep P, Greijer AE, Shvarts A, Meijer S, Pinedo HM, Semenza GL, van Diest PJ, van der Wall E (2003) Levels of hypoxiainducible factor-1alpha independently predict prognosis in patients with lymph node negative breast carcinoma. Cancer 97: 1573-1581

Bouzubar N, Walker KJ, Griffiths K, Ellis IO, Elston CW, Robertson JF, Blamey RW, Nicholson RI (1989) Ki67 immunostaining in primary breast cancer: pathological and clinical associations. $\mathrm{Br}$ J Cancer 59: $943-947$ 
Brown RW, Allred CD, Clark GM, Osborne CK, Hilsenbeck SG (1996) Prognostic value of Ki-67 compared to S-phase fraction in axillary nodenegative breast cancer. Clin Cancer Res 2: 585-592

Bukholm IR, Bukholm G, Holm R, Nesland JM (2003) Association between histology grade, expression of HsMCM2, and cyclin A in human invasive breast carcinomas. J Clin Pathol 56: 368 - 373

Caly M, Genin P, Ghuzlan AA, Elie C, Freneaux P, Klijanienko J, Rosty C, Sigal-Zafrani B, Vincent-Salomon A, Douggaz A, Zidane M, Sastre-Garau $X$ (2004) Analysis of correlation between mitotic index, MIB1 score and S-phase fraction as proliferation markers in invasive breast carcinoma. Methodological aspects and prognostic value in a series of 257 cases. Anticancer Res 24: 3283-3288

Cattoretti G, Becker MH, Key G, Duchrow M, Schluter C, Galle J, Gerdes J (1992) Monoclonal antibodies against recombinant parts of the Ki-67 antigen (MIB 1 and MIB 3) detect proliferating cells in microwaveprocessed formalin-fixed paraffin sections. J Pathol 168: 357-363

Ceccarelli C, Trere D, Santini D, Taffurelli M, Chieco P, Derenzini M (2000) AgNORs in breast tumours. Micron 31: 143-149

Clahsen PC, van de Velde CJ, Duval C, Pallud C, Mandard AM, DelobelleDeroide A, van den Broek L, van de Vijver MJ (1999) The utility of mitotic index, oestrogen receptor and $\mathrm{Ki}-67$ measurements in the creation of novel prognostic indices for node-negative breast cancer. Eur J Surg Oncol 25: 356-363

Colozza M, Azambuja E, Cardoso F, Sotiriou C, Larsimont D, Piccart MJ (2005) Proliferative markers as prognostic and predictive tools in early breast cancer: where are we now? Ann Oncol 16: $1723-1739$

Costarelli L, Piro FR, Fortunato L, Vitelli CE, Farina M, Taffuri M, Amini M, Nofroni I (2005) Predictive variables of lymphatic metastasis in breast carcinoma with a diameter below $2 \mathrm{~cm}$. Suppl Tumori 4: S172

Domagala W, Markiewski M, Harezga B, Dukowicz A, Osborn M (1996) Prognostic significance of tumor cell proliferation rate as determined by the MIB-1 antibody in breast carcinoma: its relationship with vimentin and p53 protein. Clin Cancer Res 2: 147-154

EBCTCG (2005) Early Breast Cancer Trialist's Collaborative Group (EBCTCG)@Effects of chemotherapy and hormonal therapy for early breast cancer on recurrence and 15-year survival: an overview of the randomised trials. Lancet 365: 1687-1717

Egger M, Zellweger-Zahner T, Schneider M, Junker C, Lengeler C, Antes G (1997) Language bias in randomised controlled trials published in English and German. Lancet 350: 326-329

Eifel P, Axelson JA, Costa J, Crowley J, Curran Jr WJ, Deshler A, Fulton S, Hendricks CB, Kemeny M, Kornblith AB, Louis TA, Markman M, Mayer R, Roter D (2001) National Institutes of Health Consensus Development Conference Statement: adjuvant therapy for breast cancer, November 13, 2000. J Natl Cancer Inst 93: 979-989

Erdem O, Dursun A, Coskun U, Gunel N (2005) The prognostic value of p53 and c-erbB-2 expression, proliferative activity and angiogenesis in nodenegative breast carcinoma. Tumori 91: 46-52

Esteva FJ, Sahin AA, Smith TL, Yang Y, Pusztai L, Nahta R, Buchholz TA, Buzdar AU, Hortobagyi GN, Bacus SS (2004) Prognostic significance of phosphorylated P38 mitogen-activated protein kinase and HER-2 expression in lymph node-positive breast carcinoma. Cancer 100: 499-506

Fresno M, Molina R, Perez del Rio MJ, Alvarez S, Diaz-Iglesias JM, Garcia I, Herrero A (1997) p53 expression is of independent predictive value in lymph node-negative breast carcinoma. Eur J Cancer 33: 1268-1274

Gaglia P, Bernardi A, Venesio T, Caldarola B, Lauro D, Cappa AP, Calderini P, Liscia DS (1993) Cell proliferation of breast cancer evaluated by antiBrdU and anti-Ki-67 antibodies: its prognostic value on short-term recurrences. Eur J Cancer 29A: 1509-1513

Galiegue S, Casellas P, Kramar A, Tinel N, Simony-Lafontaine J (2004) Immunohistochemical assessment of the peripheral benzodiazepine receptor in breast cancer and its relationship with survival. Clin Cancer Res 10: $2058-2064$

Gasparini G, Bevilacqua P, Pozza F, Meli S, Boracchi P, Marubini E, Sainsbury JR (1992) Value of epidermal growth factor receptor status compared with growth fraction and other factors for prognosis in early breast cancer. Br J Cancer 66: 970 - 976

Gasparini G, Boracchi P, Bevilacqua P, Mezzetti M, Pozza F, Weidner N. (1994) A multiparametric study on the prognostic value of epidermal growth factor receptor in operable breast carcinoma. Breast Cancer Res Treat 29: $59-71$

Gerdes J, Schwab U, Lemke H, Stein H (1983) Production of a mouse monoclonal antibody reactive with a human nuclear antigen associated with cell proliferation. Int J Cancer 31: 13-20
Glinsky GV, Berezovska O, Glinskii AB (2005) Microarray analysis identifies a death-from-cancer signature predicting therapy failure in patients with multiple types of cancer. $J$ Clin Invest 115: 1503-1521

Goldhirsch A, Wood WC, Gelber RD, Coates AS, Thurlimann B, Senn HJ (2003) Meeting highlights: updated international expert consensus on the primary therapy of early breast cancer. J Clin Oncol 21: 3357-3365

Gonzalez MA, Pinder SE, Callagy G, Vowler SL, Morris LS, Bird K, Bell JA, Laskey RA, Coleman N (2003) Minichromosome maintenance protein 2 is a strong independent prognostic marker in breast cancer. J Clin Oncol 21: $4306-4313$

Goodson WH, Moore DH III, Ljung BM II, Chew K, Mayall B, Smith HS, Waldman FM (2000) The prognostic value of proliferation indices: a study with in vivo bromodeoxyuridine and Ki-67. Breast Cancer Res Treat 59: $113-123$

Greenland S (1994) Invited commentary: a critical look at some popular meta-analytic methods. Am J Epidemiol 140: 290-296

Gregoire G, Derderian F, Le Lorier J (1995) Selecting the language of the publications included in a meta-analysis: is there a Tower of Babel bias? J Clin Epidemiol 48: 159-163

Haerslev T, Jacobsen GK, Zedeler K (1996) Correlation of growth fraction by Ki-67 and proliferating cell nuclear antigen (PCNA) immunohistochemistry with histopathological parameters and prognosis in primary breast carcinomas. Breast Cancer Res Treat 37: 101-113

Harbeck N, Dettmar P, Thomssen C, Berger U, Ulm K, Kates R, Hofler H, Janicke F, Graeff H, Schmitt M (1999) Risk-group discrimination in node-negative breast cancer using invasion and proliferation markers: 6-year median follow-up. Br J Cancer 80: 419-426

Hayes DF (2005) Prognostic and predictive factors revisited. Breast 14: $493-499$

Heatley MK, Ewings P, Odling Smee W, Maxwell P, Toner PG (2002) Vimentin expression does not assist in predicting survival in ductal carcinoma of the breast. Pathology 34: 230-232

Hlupic L, Jakic-Razumovic J, Bozikov J, Coric M, Belev B, Vrbanec D (2004) Prognostic value of different factors in breast carcinoma. Tumori 90: $112-119$

Jacquemier JD, Penault-Llorca FM, Bertucci F, Sun ZZ, Houvenaeghel GF, Geneix JA, Puig BD, Bardou VJ, Hassoun JA, Birnbaum D, Viens PJ (1998) Angiogenesis as a prognostic marker in breast carcinoma with conventional adjuvant chemotherapy: a multiparametric and immunohistochemical analysis. J Pathol 184: 130-135

Jalava PJ, Collan YU, Kuopio T, Juntti-Patinen L, Kronqvist P (2000) Bcl-2 immunostaining: a way to finding unresponsive postmenopausal $\mathrm{N}+$ breast cancer patients. Anticancer Res 20: 1213-1219

Jansen RL, Hupperets PS, Arends JW, Joosten-Achjanie SR, Volovics A, Schouten HC, Hillen HF (1998) MIB-1 labelling index is an independent prognostic marker in primary breast cancer. Br J Cancer 78: 460-465

Jensen V, Ladekarl M, Holm-Nielsen P, Melsen F, Soerensen FB (1995) The prognostic value of oncogenic antigen 519 (OA-519) expression and proliferative activity detected by antibody MIB-1 in node-negative breast cancer. J Pathol 176: 343-352

Keshgegian AA, Cnaan A (1995) Proliferation markers in breast carcinoma. Mitotic figure count, S-phase fraction, proliferating cell nuclear antigen, Ki-67 and MIB-1. Am J Clin Pathol 104: $42-49$

Kroger N, Milde-Langosch K, Riethdorf S, Schmoor C, Schumacher M, Zander AR, Loning T (2006) Prognostic and predictive effects of immunohistochemical factors in high-risk primary breast cancer patients. Clin Cancer Res 12: 159-168

Kronblad A, Jirstrom K, Ryden L, Nordenskjold B, Landberg G (2006) Hypoxia inducible factor-1alpha is a prognostic marker in premenopausal patients with intermediate to highly differentiated breast cancer but not a predictive marker for tamoxifen response. Int J Cancer 118: $2609-2616$

Kushlinskii NE, Orinovskii MB, Gurevich LE, Kazantseva IA, Talaeva S, Ermilova VD, Dvorova EK, Ozherel'ev AS, Letiagin VP (2004) The specificity of expression of molecular biological markers in tumors of the mammary gland. Vestn Ross Akad Med Nauk 5: 32-36

Lampe B, Hantschmann P, Dimpfl T (1998) Prognostic relevance of immunohistology, tumor size and vascular space involvement in axillary node negative breast cancer. Arch Gynecol Obstet 261: 139-146

Lau R, Grimson R, Sansome C, Tornos C, Moll UM (2001) Low levels of cell cycle inhibitor p27kip1 combined with high levels of Ki-67 predict shortened disease-free survival in $\mathrm{T} 1$ and $\mathrm{T} 2$ invasive breast carcinomas. Int J Oncol 18: 17-23

Lelle RJ (1990) In situ determination of the Ki-67 growth fraction (Ki-67 GF) in human tumors (studies in breast cancer). Acta Histochem Suppl 39: 109- 124 
Liu D, Baltayan A, Naritoku WY, Barr NJ, Young LL, Chaiwun B, Tsao-Wei DD, Groshen SL, Taylor CR, Torloni H, Neville AM, Cote RJ, Imam SA (2000) LEA. 135 expression: its comparison with other prognostic biomarkers for patients with primary breast carcinoma. Anticancer Res 20: $1451-1461$

Liu S, Edgerton SM, Moore DH, Thor AD II (2001) Measures of cell turnover (proliferation and apoptosis) and their association with survival in breast cancer. Clin Cancer Res 7: 1716-1723

Locker AP, Birrell K, Bell JA, Nicholson RI, Elston CW, Blamey RW, Ellis IO (1992) Ki67 immunoreactivity in breast carcinoma: relationships to prognostic variables and short term survival. Eur J Surg Oncol 18: $224-229$

McShane LM, Altman DG, Sauerbrei W, Taube SE, Gion M, Clark GM (2005) Reporting recommendations for tumor marker prognostic studies. J Clin Oncol 23: $9067-9072$

Michalides R, van Tinteren H, Balkenende A, Vermorken JB, Benraadt J, Huldij J, van Diest P (2002) Cyclin A is a prognostic indicator in early stage breast cancer with and without tamoxifen treatment. $\mathrm{Br} J$ Cancer 86: $402-408$

Michels JJ, Duigou F, Marnay J, Henry-Amar M, Delozier T, Denoux Y, Chasle J (2003) Flow cytometry and quantitative immunohistochemical study of cell cycle regulation proteins in invasive breast carcinoma: prognostic significance. Cancer 97: 1376-1386

Miller LD, Smeds J, George J, Vega VB, Vergara L, Ploner A, Pawitan Y, Hall P, Klaar S, Liu ET, Bergh J (2005) An expression signature for p53 status in human breast cancer predicts mutation status, transcriptional effects, and patient survival. Proc Natl Acad Sci USA 102: 13550-13555

Molino A, Micciolo R, Turazza M, Bonetti F, Piubello Q, Bonetti A, Nortilli R, Pelosi G, Cetto GL (1997) Ki-67 immunostaining in 322 primary breast cancers: associations with clinical and pathological variables and prognosis. Int J Cancer 74: $433-437$

Mottolese M, Benevolo M, Del Monte G, Buglioni S, Papaldo P, Nistico C, Di Filippo F, Vasselli S, Vici P, Botti C (2000) Role of P53 and BCL-2 in high-risk breast cancer patients treated with adjuvant anthracyclinebased chemotherapy. J Cancer Res Clin Oncol 126: $722-729$

Oh DS, Troester MA, Usary J, Hu Z, He X, Fan C, Wu J, Carey LA, Perou CM (2006) Estrogen-regulated genes predict survival in hormone receptor-positive breast cancers. J Clin Oncol 24: 1656-1664

Oxman AD, Clarke MJ, Stewart LA (1995) From science to practice. Metaanalyses using individual patient data are needed. JAMA 274: 845-846

Paik S, Shak S, Tang G, Kim C, Baker J, Cronin M, Baehner FL, Walker MG, Watson D, Park T, Hiller W, Fisher ER, Wickerham DL, Bryant J, Wolmark N (2004) A multigene assay to predict recurrence of tamoxifentreated, node-negative breast cancer. $N$ Engl J Med 351: 2817-2826

Paik S, Tang G, Shak S, Kim C, Baker J, Kim W, Cronin M, Baehner FL, Watson D, Bryant J, Costantino JP, Geyer Jr CE, Wickerham DL, Wolmark N (2006) Gene expression and benefit of chemotherapy in women with node-negative, estrogen receptor-positive breast cancer. J Clin Oncol 24: 3726-3734

Parmar MK, Torri V, Stewart L (1998) Extracting summary statistics to perform meta-analyses of the published literature for survival endpoints. Stat Med 17: $2815-2834$

Pellikainen MJ, Pekola TT, Ropponen KM, Kataja VV, Kellokoski JK, Eskelinen MJ, Kosma VM (2003) p21WAF1 expression in invasive breast cancer and its association with p53, AP-2, cell proliferation, and prognosis. J Clin Pathol 56: 214-220

Perou CM, Jeffrey SS, van de Rijn M, Rees CA, Eisen MB, Ross DT, Pergamenschikov A, Williams CF, Zhu SX, Lee JC, Lashkari D, Shalon D, Brown PO, Botstein D (1999) Distinctive gene expression patterns in human mammary epithelial cells and breast cancers. Proc Natl Acad Sci USA 96: 9212 - 9217

Pestalozzi BC, Luporsi-Gely E, Jost LM, Bergh J (2005) ESMO Minimum Clinical Recommendations for diagnosis, adjuvant treatment and followup of primary breast cancer. Ann Oncol 16(Suppl 1): i7-i9

Piedbois P, Buyse M (2004) Meta-analyses based on abstracted data: a step in the right direction, but only a first step. J Clin Oncol 22: $3839-3841$

Pierga JY, Leroyer A, Viehl P, Mosseri V, Chevillard S, Magdelenat H (1996) Long term prognostic value of growth fraction determination by Ki-67 immunostaining in primary operable breast cancer. Breast Cancer Res Treat 37: $57-64$

Pietilainen T, Lipponen P, Aaltomaa S, Eskelinen M, Kosma VM, Syrjanen $\mathrm{K}$ (1996) The important prognostic value of Ki-67 expression as determined by image analysis in breast cancer. J Cancer Res Clin Oncol 122: $687-692$
Pinder SE, Wencyk P, Sibbering DM, Bell JA, Elston CW, Nicholson R, Robertson JF, Blamey RW, Ellis IO (1995) Assessment of the new proliferation marker MIB1 in breast carcinoma using image analysis: associations with other prognostic factors and survival. $\mathrm{Br}$ J Cancer 71: $146-149$

Pinto AE, Andre S, Pereira T, Nobrega S, Soares J (2001) Prognostic comparative study of $\mathrm{S}$-phase fraction and $\mathrm{Ki}-67$ index in breast carcinoma. J Clin Pathol 54: 543-549

Querzoli P, Albonico G, Ferretti S, Rinaldi R, Magri E, Indelli M, Nenci (1996) MIB-1 proliferative activity in invasive breast cancer measured by image analysis. J Clin Pathol 49: 926-930

Railo M, Lundin J, Haglund C, von Smitten K, von Boguslawsky K, Nordling S (1997) Ki-67, p53, Er-receptors, ploidy and S-phase as prognostic factors in $\mathrm{T} 1$ node negative breast cancer. Acta Oncol 36: $369-374$

Railo M, Nordling S, von Boguslawsky K, Leivonen M, Kyllonen L, von Smitten K (1993) Prognostic value of Ki-67 immunolabelling in primary operable breast cancer. Br J Cancer 68: 579-583

Rudas M, Gnant MF, Mittlbock M, Neumayer R, Kummer A, Jakesz R, Reiner G, Reiner A (1994) Thymidine labeling index and Ki-67 growth fraction in breast cancer: comparison and correlation with prognosis. Breast Cancer Res Treat 32: 165-175

Rudolph P, Alm P, Heidebrecht HJ, Bolte H, Ratjen V, Baldetorp B, Ferno M, Olsson H, Parwaresch R (1999a) Immunologic proliferation marker $\mathrm{Ki}-\mathrm{S} 2$ as prognostic indicator for lymph node-negative breast cancer. J Natl Cancer Inst 91: 271-278

Rudolph P, MacGrogan G, Bonichon F, Frahm SO, de Mascarel I, Trojani M, Durand M, Avril A, Coindre JM, Parwaresch R (1999b) Prognostic significance of Ki-67 and topoisomerase IIalpha expression in infiltrating ductal carcinoma of the breast. A multivariate analysis of 863 cases. Breast Cancer Res Treat 55: 61-71

Sahin AA, Ro J, Ro JY, Blick MB, el-Naggar AK, Ordonez NG, Fritsche HA, Smith TL, Hortobagyi GN, Ayala AG (1991) Ki-67 immunostaining in node-negative stage I/II breast carcinoma. Significant correlation with prognosis. Cancer 68: 549-557

Seshadri R, Leong AS, McCaul K, Firgaira FA, Setlur V, Horsfall DJ (1996) Relationship between p53 gene abnormalities and other tumour characteristics in breast-cancer prognosis. Int J Cancer 69: 135-141

Sotiriou C, Wirapati P, Loi S, Haibe-Kains B, Desmedt C, Tutt A, Ellis P, Buyse M, Delorenzi M, Piccart MJ (2006) Comprehensive analysis integrating both clinicopathological and gene expression data in more than 1500 samples: proliferation captured by gene expression grade index appears to be the strongest prognostic factor in breast cancer (BC). J Clin Oncol 24: 4S (Abstract 507)

Spyratos F, Ferrero-Pous M, Trassard M, Hacene K, Phillips E, TubianaHulin M, Le Doussal V (2002) Correlation between MIB-1 and other proliferation markers: clinical implications of the MIB-1 cutoff value. Cancer 94: $2151-2159$

Stewart LA, Parmar MK (1993) Meta-analysis of the literature or of individual patient data: is there a difference? Lancet 341: 418-422

Thor AD, Liu S, Moore DH, Edgerton SM II (1999) Comparison of mitotic index, in vitro bromodeoxyuridine labeling, and MIB-1 assays to quantitate proliferation in breast cancer. J Clin Oncol 17: $470-477$

Topic B, Stankovic N, Savjak D, Grbic S (2002) Correlation of size of the primary tumor and axillary node status with the p53 tumor suppressor gene in carcinoma of the breast. Vojnosanit Pregl 59: 29-32

Trihia H, Murray S, Price K, Gelber RD, Golouh R, Goldhirsch A, Coates AS, Collins J, Castiglione-Gertsch M, Gusterson BA (2003) Ki-67 expression in breast carcinoma: its association with grading systems, clinical parameters, and other prognostic factors - a surrogate marker? Cancer 97: 1321 - 1331

Tsutsui S, Yasuda K, Suzuki K, Tahara K, Higashi H, Era S (2005) Macrophage infiltration and its prognostic implications in breast cancer: the relationship with VEGF expression and microvessel density. Oncol Rep 14: $425-431$

Tynninen O, von Boguslawski K, Aronen HJ, Paavonen T (1999) Prognostic value of vascular density and cell proliferation in breast cancer patients. Pathol Res Pract 195: 31 - 37

Urruticoechea A, Smith IE, Dowsett M (2005) Proliferation marker Ki-67 in early breast cancer. J Clin Oncol 23: $7212-7220$

van't Veer LJ, Dai H, van de Vijver MJ, He YD, Hart AA, Mao M, Peterse HL, van der Kooy K, Marton MJ, Witteveen AT, Schreiber GJ, Kerkhoven RM, Roberts C, Linsley PS, Bernards R, Friend SH (2002) Gene expression profiling predicts clinical outcome of breast cancer. Nature 415: $530-536$ 
Veronese SM, Maisano C, Scibilia J (1995) Comparative prognostic value of Ki-67 and MIB-1 proliferation indices in breast cancer. Anticancer Res 15: $2717-2722$

Wang Y, Klijn JG, Zhang Y, Sieuwerts AM, Look MP, Yang F, Talantov D, Timmermans M, Meijer-van Gelder ME, Yu J, Jatkoe T, Berns EM, Atkins D, Foekens JA (2005) Gene-expression profiles to predict distant metastasis of lymph-node-negative primary breast cancer. Lancet 365: 671-679

Weikel W, Beck T, Mitze M, Knapstein PG (1991) Immunohistochemical evaluation of growth fractions in human breast cancers using monoclonal antibody Ki-67. Breast Cancer Res Treat 18: 149-154

Weikel W, Brumm C, Wilkens C, Beck T, Knapstein PG (1995) Growth fractions (Ki-67) in primary breast cancers, with particular reference to node-negative tumors. Cancer Detect Prev 19: 446-450
Whitfield ML, George LK, Grant GD, Perou CM (2006) Common markers of proliferation. Nat Rev Cancer 6: 99-106

Wintzer HO, Zipfel I, Schulte-Monting J, Hellerich U, von Kleist S (1991) Ki-67 immunostaining in human breast tumors and its relationship to prognosis. Cancer 67: $421-428$

Yang Q, Sakurai T, Yoshimura G, Suzuma T, Umemura T, Nakamura M, Nakamura Y, Mori I, Kakudo K (2003) Prognostic value of Bcl-2 in invasive breast cancer receiving chemotherapy and endocrine therapy. Oncol Rep 10: $121-125$

Yusuf S, Peto R, Lewis J, Collins R, Sleight P (1985) Beta blockade during and after myocardial infarction: an overview of the randomized trials. Prog Cardiovasc Dis 27: 335-371 